\title{
RARE-EARTH ELEMENTS RECOVERY ON THE EXAMPLE OF EUROPIUM (III) FROM LEAN TECHNOGENIC RAW MATERIALS
}

\author{
Olga Lobacheva ${ }^{1}$, Natalia Dzhevaga ${ }^{1}$ \\ 1 Saint-Petersburg Mining University, Vasilievskiy Island 21 ${ }^{\text {st }}$, Line 2, 199106, Saint-Petersburg, Russian \\ Federation, e-mail: olga-59@yandex.ru
}

Received: 2017.08.28

Accepted: 2017.09.30

Published: 2017.11.01

\begin{abstract}
Europium (III) recovery from nitrate solutions in a form of dodecyl sulfates using extraction methods was studied. Distribution and recovery coefficients as a function of equilibrium aqueous phase $\mathrm{pH}$ value were received. Conclusions on the effectiveness of presented method depending on the assigned task were drawn. The aims of this study were the development of rare-earth elements recovery and separation methods by using extraction with surfactant and distribution coefficients separation as well as recovery coefficient experimental validation with their subsequent introduction for poor mineral raw materials industrial processing. The authors study the rare-earth metals distribution and recovery coefficients during the extraction processes as a function of aqueous phase $\mathrm{pH}$ value with recovered compound form determination and thermodynamical justification.
\end{abstract}

Keywords: recovery, separation, extraction, rare-earth elements, distribution coefficients

\section{INTRODUCTION}

Day by day, the extraction processes find a wide application in different national economy enterprises. This is explained by process selectivity and simplicity, high running rates and efficiency at low initial concentrations of metal cations.

Many researchers are studying rare-earth elements extraction process by carboxylic acids, because their usage as extractants in sulfuric and hydrochloric acid technologies of rare-earth metals raw materials processing is found to be more effective, than, e.g. organophosphorus compounds [1]. Distribution coefficient values for cerium extraction by naphthenic acid, obtained in paper [2], appeared to be much lower than during its extraction by oleic acid. The results of cerium (III) extraction in the conditions that are close to industrial (strongly acidic solution with sulphuric acid content $0.37-4.37 \mathrm{~mol} / \mathrm{kg}$ ) by using trialkyl benzil ammonium sulfate in xylol with concentration of $0.5 \mathrm{M}$ are presented in paper [3].

Researchers [4] filled in the gap in lanthanide (III) nitrates extraction chemistry with trialkyl benzil ammonium naphthenate. The phase ratio was $2: 1$. Rare-earth elements are recovered into organic phase as $(\mathrm{R} 4 \mathrm{~N})_{2}\left[\mathrm{Ln}\left(\mathrm{NO}_{3}\right)_{3}(\mathrm{RCOO})_{2}\right]$. In the series from lanthanum to lutetium, extraction is decreased; at the same time yttrium recovery ratio is significantly lower than that for lanthanides. Trialkyl benzil ammonium naphthenate can be used for the separation of lantanides with smaller sequence number from other lantanides and systems of yttrium compounds removal from lantanides.

A method of lanthanum, thorium and yttrium extraction by porous carriers and liquid extragent based composite materials is promising [5]. In the case of thorium (IV), lanthanum (III) and yttrium (III) coextraction from water-salt solutions by composite material based on polystyrene supercrosslinked by trialkyle amine (TAA), lanthane (III) and yttrium (III) nitrates are virtually not consumed, and when lantanum (III) and yttrium (III) concentrations are increased in aqueous phase, thorium (IV) nitrate content in compound material phase is raised as well [6]. This system can be used for cleaning of rare-earth metals ni- 
trates concentrated solutions from thorium (IV) foreign material, similarly as above.

The data on rare-earth metals extraction from nitrate solutions with fluoride ions is available [7]. In paper [8], zirconium (IV) cations extraction recovery from sulfuric and nitric solutions in the presence of fluoride ions by trialkyl benzil ammonium sulfate and nitrate (TABAS and TABAN) solutions in xylol was studied.

The extraction method can be used for recovering metal cations from diluted industrial waste solutions (molybdenum, copper, coppernickel, apatite-nephelinic and eudialyte ores and red muds).

The literature sources indicate the complexity of rare-earth metals recovery and separation by using extraction methods, and prove the necessity of multilateral and detailed study of these processes. The extraction using surfactants with thermodynamical justification of obtained process values is prospective.

The innovative idea of this research is using the extraction method for rare-earth metals recovery and separation from weak solutions. An advantage of the proposed method over the similar ones is a possibility of selective recovery of the target component from diluted process solutions and the use of widespread surfactants.

When solving the assigned tasks, using sodium dodecyl sulfate as surfactant is proposed, because it combines the properties of foaming and collecting agents and has the following advantages over other surfactants: non-toxic (IV class of hazard); low price; the amounts of NaDS needed for process realization conform to stoichiometry; possibility of using NaDS over a wide range of liquid phase acidity; recoverability from products; compared to similar surfactants rare-earth metals recovery ratio by sodium dodecyl sulfate has maximum values.

The research presented in this paper is currently aimed at studying of major and alternative rare-earth metals sources, methods of their recovery and separation. According to the literature, the following minerals are the cost-efficient sources of rare-earth raw materials: bastnaesite $-\mathrm{Ln}\left(\mathrm{CO}_{3}\right)$ $\mathrm{F}(70-75 \%)$, turnerite $-\mathrm{LnPO}_{4}(55-60 \%)$, loparite - $\mathrm{NaCaLn}\left(\mathrm{TiO}_{3}\right)_{2}\left(\mathrm{NbO}_{3}\right)_{2}(30-35 \%)$, xenotime (Y, Eu, Gd)PO $\mathrm{PO}_{4}(55-60 \%)$. The lean technogenic wastes, received in the course of industrial materials production constitute alternative sources of rare-earth metals. These include: converter dusts, slags, red muds from aluminum production; lean mineral raw materials.
The modern technologies for obtaining raremetal raw materials are aimed at obtaining rareearth metals from minerals from various mineral deposits [9]. At the current stage of industrial development, Russia has no owned deposits of clean rare-earth raw materials, such as bastnaesite, turnerite and xenotime, which are used as a basis for foreign rare-earth industry. In Russia, the most accessible and efficient materials for processing are lean eudialyte and Khibini apatite-nephelinic ores of Kola Peninsula. Currently, Russian rare-earth industry operates on rare-earth metals production when developing new deposits, which is not nearly complete enough for supplying the growing requirements for rare-metals and their derivatives. For the development of Russian rare-metal industry, special attention should be paid to accompanying recovery of individual rare-earth metals when processing polycomponent ores, rather than the development of new deposits. Multipurpose use of mineral raw materials is the most important direction for resource-saving in the new millennium. Because separated rare-earth metals are of extrinsic value, an increase of recovery and separation effectiveness of rare-earth elements with close physicochemical properties is a pressing problem, enabling to lower the cost of individual rare-earth metals and their compounds as well as expand the possibility of their use.

The current world science research guidelines are directed towards the increase of recovery and separation effectiveness of rare-earth elements by using extraction methods not only from the end product, but also from industrial waste products [10-13].

\section{MATERIALS AND METHODS}

All reagents used in this research are chemically pure and have quality certificates. Europium nitrate solution with concentration $0.01 \mathrm{M}$ was prepared by dissolution of $\mathrm{Eu}\left(\mathrm{NO}_{3}\right)_{3} \cdot 5 \mathrm{H}_{2} \mathrm{O}$ sample with $99.9 \%$ purity in distilled water. All the subsequent process solutions were prepared from this solution by dilution to $0.001 \mathrm{M}$ concentration. Precise concentration value of the initial solution was checked by sample titration by EDTA with Xylenol orange indicator. $\mathrm{Er}\left(\mathrm{NO}_{3}\right)_{3} \cdot 5 \mathrm{H}_{2} \mathrm{O}$, $\mathrm{Ho}\left(\mathrm{NO}_{3}\right)_{3} \cdot 5 \mathrm{H}_{2} \mathrm{O}$ and $\mathrm{Sm}\left(\mathrm{NO}_{3}\right)_{3} \cdot 6 \mathrm{H}_{2} \mathrm{O}$ solutions for rare-earth elements total recovery were prepared and titrated similarly. Sodium dodecyl sulfate for biochemistry ( $\mathrm{NaDS}, \mathrm{C}_{12} \mathrm{H}_{25} \mathrm{OSO}_{3} \mathrm{Na}$ ) 
manufactured by Acrosorganics (USA) with $99 \%$ purity was used as surfactant. During the test, a sample of NaDS was added to the working solution. Only fresh nitric acid and sodium hydroxide for setting the required $\mathrm{pH}$ value were used. Isooctyl alcohol (2-ethyl-1-hexanol) with $96 \%$ purity used as extractant was manufactured by Aldrich (USA).

Europium dodecyl sulfate recovery into organic phase was conducted by liquid extraction method. Isooctyl alcohol was used as the extractant. Sodium dodecyl sulfate was used as "carrier agent" for carrying europium cations from the aqueous phase to the organic phase. Sodium dodecyl sulfate was added into solution, in accordance with stoichiometry of the following reaction:

$$
\mathrm{Eu}^{3+}+3 \mathrm{C}_{12} \mathrm{H}_{25} \mathrm{OSO}_{3}^{-}=\mathrm{Eu}\left(\mathrm{C}_{12} \mathrm{H}_{25} \mathrm{OSO}_{3}\right)_{3}
$$

its concentration was $0.003 \mathrm{M}$. pH value was adjusted to the required value by batchwise addition of $\mathrm{NaOH} 1 \mathrm{~N}$ alcaline solution or diluted nitric acid $\mathrm{HNO}_{3}$. The $\mathrm{pH}$ value of aqueous solutions was determined by using a $\mathrm{pH}$-meter "pH-150 MA".

Aqueous and organic phase volumes were $200 \mathrm{ml}$ and $5 \mathrm{ml}$, respectively. The process was conducted at ES-8300 D overhead extractor for 30 minutes at approx. 700 RPM. The extraction process parameters were deduced from the experiments and permit achieving maximum results. The form of salts extracted to organic phase was determined by means of infrared spectroscopy method with Nicolet 6700 spectrometer.

Extraction recovery of europium (III) cations in the compresence of holmium (III), erbium (III) and samarium (III) cations was conducted by the method described above. Working solutions containing in the compresence of $\mathrm{Sm}^{3+}, \mathrm{Eu}^{3+}, \mathrm{Ho}^{3+}$ and $\mathrm{Er}^{3+}$, were prepared by mixing $50 \mathrm{ml}$ solutions for each element having $0.001 \mathrm{M}$ concentration. The volume of solution with final total concentration of $0.001 \mathrm{M}$ was $200 \mathrm{ml}$. Extracted elements concentration determination in the compresence in aqueous phase was conducted by photometric method of optical emission spectroscopy with inductively coupled plasma on ICPE-9000 (Simadzu) spectrometer. Spectrometer calibration was conducted by using standard samples for ICPCertiPUR (MERCK).

The content of europium cations recovered to organic phase during the extraction from individual solutions was determined from the concentration difference of original and equilibrium aque- ous phases with consideration for phase volumes relationship:

$$
C_{\text {org }}=\frac{\left(C_{0}-C_{a q}\right) \cdot V_{a q}}{V_{o r g}}
$$

where: $C_{0}$ - europium cations initial content in aqueous phase, $\mathrm{mol} / \mathrm{l}$;

$C_{\text {org }}$ - holmium cationos concentration in organic phase, $\mathrm{mol} / \mathrm{l}$;

$C_{a q}$ - europium cations in aqueous phase, $\mathrm{mol} / \mathrm{l}$

$V_{\text {org }}$ - organic phase volume, $\mathrm{ml}$;

$V_{a q}^{o r g}$-aqueous phase volume, $\mathrm{ml}$.

Europium (III) cations distribution coefficient in individual solutions $\left(\mathrm{K}_{\text {distr }}\right)$ and in the presence of holmium (III), erbium (III) and samarium (III) $\left(K_{\text {distr } \Sigma}\right)$ was calculated as a ratio of molar concentrations of target component in organic and aqueous phases in accordance with [14].

\section{RESULTS}

Figures 1 and 2 present the results of europium dodecyl sulfates extraction recovery from nitrate solutions in the range of $\mathrm{pH} 2.0-11.0$. As Figure 1 shows, the maximum distribution coefficient during the extraction is observed at $\mathrm{pH}=4.0$.

In accordance with the results of papers [15, 16], the Gibbs energy of $\mathrm{Ho}(\mathrm{OH})^{2+}$ monohydroxocomplex formation from the elements $\Delta_{f} G_{298}^{0}$ and ions $\Delta_{\text {compl }} G_{298}^{0}$ is -782.60 and $-47.42 \mathrm{~kJ} /$ $\mathrm{mol}, \mathrm{Eu}(\mathrm{OH})_{3}$ hydroxide $-1199.11 \mathrm{~kJ} / \mathrm{mol}$ and $149.23 \mathrm{~kJ} / \mathrm{mol}$; $\mathrm{pH}$ of complex formation $\mathrm{pH}_{\text {compl }}$ is 5.80 , and $\mathrm{pH}$ of hydrate formation $\mathrm{pH}_{\text {hydr }}-$ 6.52 , i.e. $\mathrm{pH}$ values, at which hydroxocomplex formation of $\mathrm{Eu}(\mathrm{OH})^{2+}$ and hydroxide $\mathrm{Eu}(\mathrm{OH})_{3}$ formation begins.

Table 1. Results of europium (III) cations extraction experimental study.

\begin{tabular}{|c|c|c|c|}
\hline $\mathrm{pH}$ & $\begin{array}{c}{\left[\mathrm{Eu}^{3+}\right]_{\mathrm{aq}} \times 10^{4}} \\
\mathrm{~mol} / \mathrm{kg}\end{array}$ & $\begin{array}{c}{\left[\mathrm{Eu}^{3+}\right]_{\mathrm{org}} \times 10^{2}} \\
\mathrm{~mol} / \mathrm{kg}\end{array}$ & $\mathrm{K}_{\text {distr }}$ \\
\hline 3.0 & 1.93 & 3.88 & 200.5 \\
\hline 3.5 & 1.82 & 3.93 & 216.1 \\
\hline 4.0 & 1.70 & 3.99 & 233.9 \\
\hline 4.5 & 1.84 & 3.92 & 213.8 \\
\hline 5.0 & 1.97 & 3.86 & 196.3 \\
\hline 5.5 & 1.94 & 3.87 & 199.4 \\
\hline 6.0 & 1.93 & 3.88 & 201.5 \\
\hline
\end{tabular}




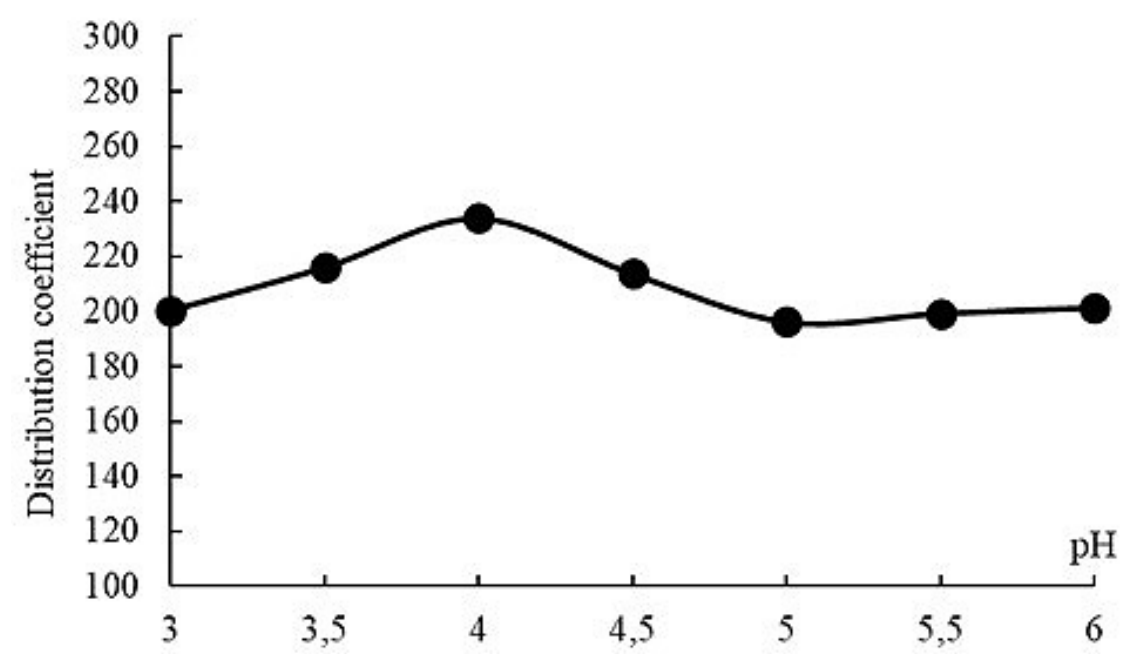

Fig. 1. Europium (III) cations distribution coefficient as a function of solution $\mathrm{pH}$ value.

During the extraction, the minimum target component concentration in the aqueous phase is observed at $\mathrm{pH}=4.0$. The dependence of aqueous phase $\mathrm{pH}$ in relation to medium acid value is weak along the entire range under study. Subsequently to the results of spent and clear isooctyl alcohol spectrum analysis, it was found that europium dodecyl sulfates are recovered to organic phase in a form of $\mathrm{Eu}\left(\mathrm{C}_{12} \mathrm{H}_{25} \mathrm{OSO}_{3}\right)_{3}$ solvates. The interaction of alcohol molecules with europium cations is confirmed by $v_{\mathrm{O}-\mathrm{H}}$ stretching frequency shift. At the same time, as we expected, there is no europium cations recovery in nitrate solutions without sodium dodecyl sulfate, because of the absence of target component screening by nonpolar hydrocarbon radicals.

The efficiency of europium sulfates recovery during the extraction is maximal at the studied $\mathrm{pH}$ range from 2.0 to 7.5 , which reflects the weak de- pendence from aqueous phase acidity. At strongly alkaline $\mathrm{pH}$ range, the efficiency of recovery by extraction is reduced.

The results of experimental studies of europium dodecyl sulfate extraction by isooctyl alcohol as extragent in the compresence of erbium (III), samarium (III) and holmium (III) are shown in Table 2.

According to the obtained results, when extracting rare-earth elements from individual solutions, maximum distribution coefficients correspond to $\mathrm{pH} 4.0-4.5$, permitting rare-earth elements recovery to organic phase in a form of alcohol solvates of tertiary dodecyl sulfates. As a result, dodecyl sulfate concentration in equilibrium aqueous phase is negligibly small. In the compresence of rare-earth elements, their distribution coefficients rise by an order of magnitude and are maximal at approx. $\mathrm{pH} 6$. With this $\mathrm{pH}$ value, a

Table 2. Rare-earth elements (III) cations depending on solution $\mathrm{pH}$ value during extraction in the compresence $\left(\mathrm{K}_{\text {distr } \Sigma}\right)$ and individually $\left(\mathrm{K}_{\text {distr }}\right)$

\begin{tabular}{|c|c|c|c|c|c|c|c|c|}
\hline \multirow{4}{*}{$\mathrm{pH}$} & \multicolumn{2}{|c|}{$\mathrm{Ho}^{3+}$} & \multicolumn{2}{|c|}{$\mathrm{Sm}^{3+}$} & \multicolumn{2}{|c|}{$\mathrm{Eu}^{3+}$} & \multicolumn{2}{|c|}{$\mathrm{Er}^{3+}$} \\
\hline & $\begin{array}{c}\mathrm{pH}_{\text {compl }} \\
\mathrm{HoOH}^{2+}\end{array}$ & $\mathrm{pH}_{\text {hydr }}$ & $\begin{array}{c}\mathrm{pH}_{\text {compl }} \\
\mathrm{SmOH}^{2+}\end{array}$ & $\mathrm{pH}_{\text {hydr }}$ & $\begin{array}{l}\mathrm{pH}_{\text {compl }} \\
\mathrm{EuOH}^{2+}\end{array}$ & $\mathrm{pH}_{\text {hydr }}$ & $\begin{array}{l}\mathrm{pH}_{\text {compl }} \\
\mathrm{ErOH}^{2+}\end{array}$ & $\mathrm{pH}_{\text {hydr }}$ \\
\hline & 6.2 & 6.6 & 5.8 & 6.5 & 5.8 & 6.5 & 5.7 & 6.4 \\
\hline & $\mathrm{K}_{\text {pacпр } \sum}$ & $\mathrm{K}_{\text {распр }}$ & $\mathrm{K}_{\text {распр } \Sigma}$ & $\mathrm{K}_{\text {распр }}$ & $\mathrm{K}_{\text {распр } \Sigma}$ & $\mathrm{K}_{\text {распр }}$ & $\mathrm{K}_{\text {распр } \Sigma}$ & $\mathrm{K}_{\text {распр }}$ \\
\hline 2.0 & 1090.3 & 414.1 & 1325.2 & 285.4 & 1178.3 & 183.2 & 1132.7 & 112.3 \\
\hline 3.0 & 1282.5 & 443.1 & 1437.3 & 306.8 & 1355.6 & 200.5 & 1355.6 & 122.9 \\
\hline 3.5 & 1322.5 & 461.5 & 1598.1 & 313.8 & 1495.8 & 216.1 & 1534.4 & 140.9 \\
\hline 4.0 & 1481.9 & 481.4 & 1752.4 & 326.1 & 1690.9 & 233.9 & 1752.4 & 163.0 \\
\hline 4.5 & 1493.1 & 455.2 & 1754.7 & 375.0 & 1691.7 & 213.8 & 1792.5 & 150.6 \\
\hline 5.0 & 1529.2 & 404.9 & 1756.3 & 426.1 & 1695.9 & 196.3 & 1818.6 & 147.7 \\
\hline 5.5 & 1985.7 & 367.9 & 2562.4 & 414.1 & 1980.4 & 199.4 & 3286.4 & 137.0 \\
\hline 6.0 & 3300.0 & 359.6 & 3091.7 & 395.5 & 3300.0 & 201.5 & 4512.2 & 132.1 \\
\hline 6.5 & 3115.2 & 310.1 & 2869.3 & 376.2 & 3141.3 & 194.2 & 4187.9 & 122.7 \\
\hline 7.0 & 2855.4 & 292.8 & 2471.5 & 351.4 & 2747.6 & 182.1 & 3681.4 & 108.1 \\
\hline
\end{tabular}


rare-earth element in the aqueous solution occurs mostly in a form of $\mathrm{Ln}(\mathrm{OH})^{2+}$ monohydroxocomplexes and it is recovered in a form of solvates of $\mathrm{Ln}(\mathrm{OH})(\mathrm{DS})_{2} \cdot \mathrm{nROH}$ basic salts. Dodecyl sulfate consumption lowers and the equilibrium shifts towards extraction.

\section{CONCLUSIONS}

A study of europium (III) cations extraction from individual water-salt solutions and in the compresence of foreign rare-earth elements cations was conducted. According to the obtained results, while using extraction method for the recovery of europium (III) cations from diluted solutions efficient, e.g. for concentrating components during wastewater treatment

a) at $\mathrm{pH}=3.0-4.5$ europium (III) cations maximum recovery for extraction method reaches $92 \%$ using isooctyl alcohol as extragent;

b) when using extraction for recovering europium (III) cations,

it was discovered that europium (III) cations $\mathrm{K}_{\text {distr }}$ increased significantly during the extraction in the copresence of foreign ions, compared to the recovery from individual solutions. The maximum recovery $\mathrm{pH}$ increased as well.

\section{Acknowledgements}

The research was conducted in accordance with the grant by the President of the Russian Federation for state support of young Russian scientists-PhDs on the project MK-14.Z56.17.424 "Intensification of foam concentrate the rare earth elements in the processing of multicomponent industrial solutions».

\section{REFERENCES}

1. Dibrov I.A., Chirkst D.E., Litvinova T.E. 2003. Extraction of yttrium (III) from sulfate solutions with trialkylbenzylammonium sulfate. Non-ferrous metals, 7, 112-115;

2. Chirkst D.E., Litvinova T.E., Starshinova V.S., Kuchina V.I. 2006. Extraction of cerium (III) by naphthenic acid from nitrate media. Russian Journal of Applied Chemistry, 79(7), 1072-1076;

3. Dibrov I.A., Chirkst D.E., Litvinova T.E. 2002. Thermodynamic modeling of cerium (III) extraction from sulfate solutions with quaternary ammonium salts. Russian Journal of Applied Chemistry, 75(2), 197-201;
4. Pyartman A.K., Kopyrin A.A., Zhikharev D.A. 2003. Extraction of nitrates of lanthanides (III) and yttrium (III) by trialkylbenzylammonium naphthenate in toluene. Russian Journal of Applied Chemistry, 76(1), 57-61;

5. Pyartman A.K., Keskinov V.A., Lishchuk V.V., Konstantinova A.V., Belova V.V. 2006. Extraction of Th (IV), La (III) and Y (III) nitrates with a polymeric carrier and trialkylmethylammonium nitrate composite material. Russian Journal of Applied Chemistry, 79(11), 1822-1826;

6. Pyartman A.K., Lishchuk V.V., Keskinov V.A. 2006. Extraction of thorium (IV), lanthanum (III) and yttrium (III) nitrates with a composite material based on a polymeric carrier and a trialkylamine. Russian Journal of Applied Chemistry, 79(8), 1280-1284;

7. Dibrov I.A., Chirkst D.E., Litvinova T.E. 1996. Thermodynamic studies of acid dissection of eudialyte concentrate. Russian Journal of Applied Chemistry, 69(5), 727-730;

8. Dibrov I.A., Chirkst D.E., Litvinova T.E. 2002. Experimental study of extraction of zirconium (IV) from fluoride-containing acidic solutions. Russian Journal of Applied Chemistry, 75(2), 202-207;

9. Danilov A., Smirnov Y., Petrova T., Pashkevich M. Using drones of preconstruction monitoring conducting in mining enterprise. 2015. International Journal of Ecology and Development, 30(1), 36-42;

10. Ksenofontov B.S. 2013. Possibilities of intensification of metal ions extraction from wastewater. Safety of vital activity, 1, 20-23;

11. Baba Y., Kubota F., Kamiya N., Goto M. 2011. Recent advances in extraction and separation of rareearth metals using ionic liquids. Journal of Chemical Engineering of Japan, 44(10), 679-685;

12. Lokshin E.P., Kalinnikov V.T., Tareeva O.A. 2012. Extraction of rare-earth elements from industrial products and technogenic wastes of processing of Khibin apatite concentrate. Non-ferrous metals, 3, 75-80;

13. Bragina V.I., Sushkina Y.V. 2012. Developing the technology of complex adoption of phosphate rareearth metal ores from the tatarskoe deposit. Russian Journal of Non-Ferrous Metals, 53(2), 111-115;

14. Lemlich R. 1972. Adsorptive bubble separation techniques. Academic Press. N-Y. London. pp. 244;

15. Chirkst D.E., Lobacheva O.L., Dzhevaga N.V. 2011. Thermodynamics of the formation of hydroxides and hydroxo complexes of lanthanum (III) and holmium (III). Russian Journal of Physical Chemistry, 85(11), 2011-2014;

16. Chirkst D.E., Lobacheva O.L., Berlinsky I.V. 2009. Thermodynamic properties of hydroxo compounds and the mechanism of ion flotation of cerium, europium and yttrium. Russian Journal of Physical Chemistry, 83(12), 2221-2226. 